IZA DP No. 10301

Assessing the Performance of School-to-Work Transition Regimes in the EU

Kari P Hadjivassiliou

Arianna Tassinari

Werner Eichhorst

Florian Wozny

October 2016 


\title{
Assessing the Performance of School-to-Work Transition Regimes in the EU
}

\author{
Kari P Hadjivassiliou \\ Institute for Employment Studies \\ Arianna Tassinari \\ Warwick Business School \\ Werner Eichhorst \\ $I Z A$
}

\section{Florian Wozny}

IZA

\section{Discussion Paper No. 10301 \\ October 2016}

\author{
IZA \\ P.O. Box 7240 \\ 53072 Bonn \\ Germany \\ Phone: +49-228-3894-0 \\ Fax: +49-228-3894-180 \\ E-mail: iza@iza.org
}

\begin{abstract}
Any opinions expressed here are those of the author(s) and not those of IZA. Research published in this series may include views on policy, but the institute itself takes no institutional policy positions. The IZA research network is committed to the IZA Guiding Principles of Research Integrity.

The Institute for the Study of Labor (IZA) in Bonn is a local and virtual international research center and a place of communication between science, politics and business. IZA is an independent nonprofit organization supported by Deutsche Post Foundation. The center is associated with the University of Bonn and offers a stimulating research environment through its international network, workshops and conferences, data service, project support, research visits and doctoral program. IZA engages in (i) original and internationally competitive research in all fields of labor economics, (ii) development of policy concepts, and (iii) dissemination of research results and concepts to the interested public.
\end{abstract}

IZA Discussion Papers often represent preliminary work and are circulated to encourage discussion. Citation of such a paper should account for its provisional character. A revised version may be available directly from the author. 


\section{ABSTRACT}

\section{Assessing the Performance of School-to-Work Transition Regimes in the EU*}

The Great Recession that has engulfed Europe since 2008 has had a profound impact on the process of young people's school-to-work (STW) transition. Countries' institutional configurations considerably matter in shaping the structure of young people's STW transitions and mediating the impact of the Great Recession on youth unemployment. Drawing upon Pohl and Walther's concept of 'youth transition regime' (2007), we have assessed the performance of selected EU countries belonging to different clusters regarding the speed, ease and quality of STW transitions. Differences in performance across regimes exists, with some faring better than others, although at the same time a common, worrying trend can be identified across clusters, comprising a progressive deterioration of the quality of youth transitions across the board, despite the positive policy intentions to strengthen and improve the efficacy of transition regimes.

JEL Classification: $\quad$ I2, J23, J24

Keywords: school-to-work, youth unemployment, transition regime, European Union

Corresponding author:

Werner Eichhorst

IZA

P.O. Box 7240

53072 Bonn

Germany

E-mail: Eichhorst@iza.org

\footnotetext{
* This paper summarizes results from a work package of the STYLE (Strategic Transitions for Youth Labour in Europe) project that has received funding from the European Union's Seventh Framework Programme for research, technological development and demonstration under Grant Agreement no. 613256.
} 


\section{Introduction}

The Great Recession that has engulfed Europe since 2008 has had a profound impact on the process of young people's school-to-work (STW) transition, exacerbating the challenges arising from the long-term structural transformations affecting youth labor markets across the European Union (EU). However, despite the impact of the crisis having been felt everywhere, profound cross-country differences in the performance of STW transition regimes persist and the type and severity of challenges faced by countries belonging to different institutional clusters considerably vary. The challenges surrounding young people's STW transitions that surfaced during the Great Recession have also acted as a catalyst for policy change in many Member States. Often following European Commission recommendations, numerous countries have embarked upon ambitious reform programs - such as the introduction of the Youth Guarantee (YG) and structural reforms of vocational education and training (VET) and activation policies - which have the potential to significantly alter the way in which STW transitions are structured.

This paper seeks to tackle two central questions pertaining to the performance and evolution of STW transition regimes in Europe during the Great Recession. First, what role have the institutional characteristics of distinct STW transition regimes played in mediating and structuring the impact of the crisis on young people's labor market situation? Second, in what ways are the policy changes introduced during and after the Great Recession changing the structure and logic of European STW transition regimes? Moreover, what are their implications for our conceptualization of youth transition regimes and - empirically - for the quality and sustainability of young people's STW transitions in the future?

Following an institutionalist approach, this chapter tackles these two analytical puzzles through a comparative case study design, drawing upon the typology of 'youth transitions regimes' advanced by Pohl and Walther (2007) as a framework for comparison. First, we investigate how country-specific institutional configurations that structure the STW transition process have mediated the impact of the crisis on young people's labor market situation between 2007 and 2015 in a sample of eight Member States belonging to different clusters. We explore how performance varied between and within country clusters, focusing especially on the mediating role of labor market regulatory institutions and policy instruments in the fields of active labor market policy (ALMPs), education and training, including VET. Our findings show that institutional legacies mattered considerably in determining the type and severity of challenges that different countries faced regarding young people's STW transition during the crisis. However, institutional factors interacted in complex ways with the broader macroeconomic environment and availability of fiscal resources.

Second, we analyze the main changes in the design of regulatory institutions and policy instruments in STW transition regimes across five country clusters between 2007 and 2015. By reviewing the main developments in three policy domains - ALMPs and NEET policies, VET and employment protection legislation (EPL) - we assess the extent to which recent reforms have brought about substantial change in the underlying logic and design of STW transition regimes in Europe, as well as whether these are likely to lead to future improvements in performance. Our analysis identifies conflicting trends of convergence and persisting divergence in institutional design in different policy areas. Institutional configurations appear to be in a state of flux, blurring the distinctive characteristics and internal coherence of the STW transition regimes captured by Pohl and Walther's (2007) typology. In terms of empirical outcomes, considerable challenges persist despite intense reform activity, and the post-crisis quality of STW transitions post-crisis appears to have deteriorated across all country clusters.

The chapter proceeds as follows. In Section 2, we outline the theoretical and case study selection framework. Section 3 presents the institutional features and performance of each of the five STW transition regimes 
represented by the eight case study countries. Section 4 discusses the main trends and implications of institutional and policy change across clusters during the crisis, before Section 5 concludes.

\section{Theoretical and Case Study Selection Framework}

Our analysis draws upon the multi-dimensional concept of 'youth transition regimes' developed by Pohl and Walther (2007). This builds upon Esping-Andersen's (1990) comparative welfare regime typology to conceptualize how specific policies designed to address youth unemployment are embedded within the wider socio-economic context and institutional structures in different country clusters and are influenced, in turn, by dominant cultural values. Their concept seeks to capture an underlying common logic in the governance and structuration of STW transition processes that groups different countries in distinct clusters.

The notion of 'transition regimes' encompasses various institutional and policy domains, including the structure of education and training systems (and their degree of stratification and standardization), features of the employment regulation regimes, social security systems and the focus of youth transition policies, especially regarding their model of activation ('supportive' or 'workfare'). Pohl and Walther's original conceptualization also includes cultural norms, namely the interpretative frames of concepts of youth and causes of labor market 'disadvantage' that dominate in different clusters. However, we do not consider cultural norms here, as we are concerned with analyzing the role of institutional configurations operating at the macro-level in shaping outcomes for young people in education and/or the labor market, as well as assessing how these change due to policy innovation. Pohl and Walther (2007) distinguish between five main types of youth transition regimes: (i) universalistic; (ii) liberal; (iii) employment-centered; (iv) sub-protective/Mediterranean; and (v) transitional/postsocialist. The distinctive features of each regime type are discussed in detail in Section 3 and summarized in Table 3.1 .

Following Pohl and Walther's (2007) typology, we conducted eight case studies in countries belonging to distinct regime types to compare the performance of differing institutional arrangements and the trajectory of institutional change between and within clusters between 2007 and 2015. As shown later, each regime type is characterized by specific challenges regarding the STW transition process, as well as a distinctive logic in the design of STW transition policies. The universalistic model is represented by the Swedish case study. Within the employmentcentered regime, we analyzed the cases of Germany, the Netherlands and France which - despite broad similarities - differ in the focus of their STW transition models, especially in their VET systems. The UK typifies the liberal regime. The Mediterranean/sub-protective regime is exemplified by Spain, while the Estonian and Polish case studies highlight different STW transition models in the transitional/post-socialist regime, which has adopted a mix of liberal and employment-centered approaches.

The country case studies were conducted by separate research teams using a common template as part of Work Package 3 of the STYLE project (except France), being analyzed comparatively by the chapter's authors. The case study methodology was mainly qualitative and involved primary data collection through interviews with policy-makers, employer organizations, trade unions and academic experts in each country. ${ }^{1}$ This was complemented by an extensive documentary review of policy documents and academic literature at the EU and

\footnotetext{
${ }^{1}$ This Chapter is based on D 3.3 and D 3.4 of STYLE. It draws on seven in-depth case studies conducted in: Estonia (Eamets and Humal, 2015), Germany (Eichhorst and Wozny, 2015), the Netherlands (Bekker et al, 2015), Poland (Slezak and Szopa, 2015), Spain (González-Menéndez et al, 2015), Sweden (Wadensjo, 2015) and the UK (Hadjivassiliou et al, 2015). The French case study did not include primary data collection and was based solely on extensive desk research.
} 
national levels, as well as secondary data analysis of key statistical and evaluation data relating to youth labor market performance in the selected countries.

Section 3 considers how regimes' institutional features affect their performance regarding the effectiveness of young people's STW transitions. This is conceptualized here as referring to the speed, ease and quality of young people's STW transitions. We measure performance through a range of empirical indicators: total and long-term youth unemployment rate, youth unemployment ratio, employment rate within three years of completing education, NEET rate, educational attainment and incidence of fixed-term employment. A comparison of indicators between 2007 and 2015 captures how different regimes have mediated the impact of the Great Recession on young people's labor market situation. Our discussion of performance determinants mainly focuses on the interaction between three institutional dimensions: the structure of the education and training system (particularly VET), employment regulation and labor market policy models, with a focus on ALMPs' characteristics.

In Section 4, we analyze how the regimes' institutional features have changed due to intense policy innovation activity during the crisis, focusing on policy changes introduced between 2007 and 2015. In particular, we assess the effects that recent policy changes may have for both the quality of future STW transition and the heuristic and conceptual validity of Pohl and Walther's (2007) typology in the current historical phase. Our analysis draws upon Rubery's (2011) concept of 'hybridization' of social models to capture the nature of ongoing institutional changes affecting youth transition policy regimes in Europe. This refers to the process whereby developments in new policy areas across traditional boundaries and paths of developments usually associated with distinct welfare regime typologies. This is useful to conceptualize ongoing changes in youth employment policy, where processes of gradual institutional change (Streeck and Thelen, 2005) and multi-faceted policy innovations appear to be slowly transforming the logic and objectives of existing policy regimes towards increased liberalization (Streeck, 2009), while attempting to address existing protection gaps (Rubery 2011). The regime hybridization concept captures the contradictory nature of existing policy innovations, emphasizing the need to re-consider the validity of existing typologies of youth transition regimes in the light of recent empirical developments.

\section{Institutional Features and Performance in Different Youth Transition Regimes}

In this section, we review the main institutional characteristics and performance issues of each STW transition regime, which are summarized in Table 3.1. 
Table 3.1 Comparative Framework

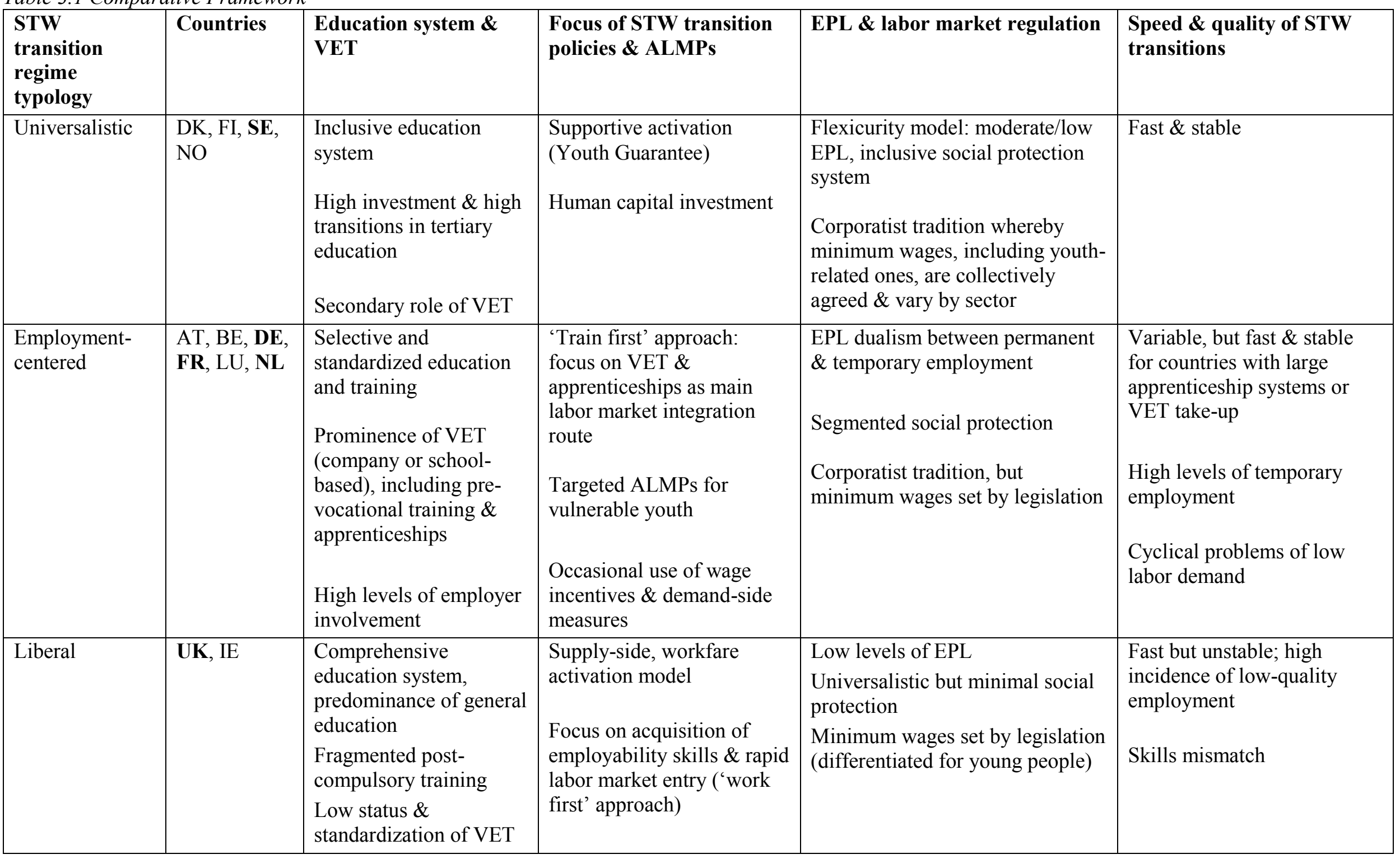




\begin{tabular}{|c|c|c|c|c|c|}
\hline & & $\begin{array}{l}\text { Limited employer } \\
\text { involvement }\end{array}$ & $\begin{array}{l}\text { Targeted remedial } \\
\text { interventions for NEETs } \\
\text { and vulnerable young } \\
\text { people }\end{array}$ & & \\
\hline $\begin{array}{l}\text { Post-socialist/ } \\
\text { Transitional }\end{array}$ & $\begin{array}{l}\text { BG, CZ, EE, } \\
\text { HU, LT, LV, } \\
\text { PL, RO, SK }\end{array}$ & $\begin{array}{l}\text { Comprehensive } \\
\text { education systems, } \\
\text { predominance of general } \\
\text { education } \\
\text { Low prominence of } \\
\text { VET (school- or } \\
\text { company-based) } \\
\text { Weak linkages between } \\
\text { education system \& } \\
\text { labor market } \\
\text { High levels of } \\
\text { educational attainment }\end{array}$ & 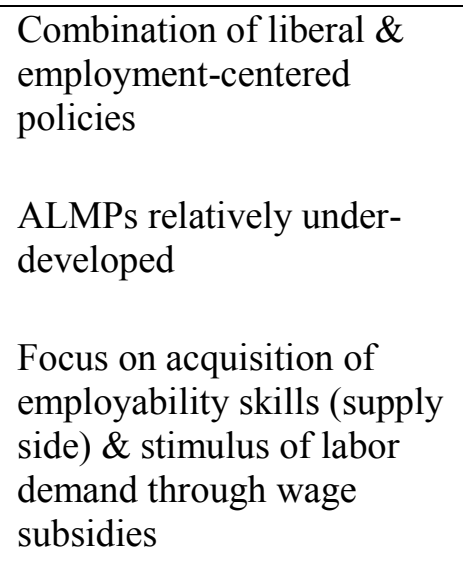 & $\begin{array}{l}\text { High EPL dualism, but } \\
\text { considerable differences within } \\
\text { cluster } \\
\text { Minimum wages set with social } \\
\text { partners involvement, not } \\
\text { differentiated by age }\end{array}$ & $\begin{array}{l}\text { Variable length \& stability } \\
\text { High incidence of } \\
\text { temporary/low-quality } \\
\text { employment } \\
\text { Skills mismatch }\end{array}$ \\
\hline
\end{tabular}

Source: Adapted from Pohl and Walther, (2007) 


\subsection{Universalistic cluster}

The 'universalistic' youth transition model - represented by Sweden - is characterized by an inclusive education system, with diversified post-compulsory routes into general and vocational education and high levels of investment in tertiary education. The linkage between education and the labor market is collinear, with employers increasingly playing a role in specifying and delivering training. Nonetheless, VET plays a secondary role in post-compulsory education compared to higher education (Wadensjö, 2015). The education and training system's comprehensive and inclusive nature is considered an important factor in facilitating human capital acquisition and smooth STW transitions. The fact that a high share of students - well-above the EU average - combine work and study also helps such transitions (Eurofound, 2014).

Sweden's strong corporatist tradition of close cooperation between social partners and the state contribute to the effectiveness of STW transition mechanisms such as traineeships/internships (Eurofound, 2014). The institutionalized nature of corporatist arrangements in 'universalistic' countries means that collective agreements constitute important driving forces for labor market regulations and wage setting (Table 3.1).

The unemployment rate for 15-24 year-olds was equal to the EU average in 2015 but far below the EU average for 25-29 year-olds (Annex Table 0.1). In general, the STW transition is comparatively fast and stable. In 2015, about $83 \%$ of $15-34$ year-olds were employed three years after completing education (Annex Table 0.2). This explains why the long-term unemployment rate (Annex Table 0.1$)$ and NEET rate are among the lowest in the eight countries and far below the EU average (Annex Table 0.2). Indeed, unemployment spells for young people tend to be rather short and refer to transitions between educational paths. However, sub-groups like the less educated, disabled or migrants face considerable barriers in entering the labor market (Wadensjö, 2015).

ALMPs are particularly developed and well-funded, and the overall STW transition model is based on young people's early activation, implemented through a highly personalized approach. In Sweden, this is realized through a strong job guarantee and social assistance program (Wadensjö, 2015). One element of such programs is intensive (and early) job search assistance, combined with personalized action plans that have proved effective short-term transition mechanisms. Supported forms of employment also play an important role.

However, in recent years, the quality and effectiveness of Sweden's education and training system have deteriorated despite strong public investment (European Commission, 2015a). Sweden is one of the few European countries where VET participation has decreased since 2005 (Gonzalez Carreras et al, 2015). Despite repeated attempts to increase the take-up of apprenticeships (Wadensjö, 2015), their incidence remains low and primarily concentrated in craft occupations, suggesting a persistent prevalence of the 'academic' higher education route as the privileged form of post-compulsory training.

This cluster's institutional setup of labor market policy is usually characterized as a 'flexicurity' example. However, over time activation has become tougher and benefit receipt less generous. Furthermore, the universalistic 'cluster' is not internally homogenous, and different regulatory regimes may apply to distinct groups in the labor market. For example, in contrast to Denmark, Sweden's EPL is relatively high for permanent but relatively low for temporary employment, leading to labor market segmentation reflected in above-EU-average levels of temporary employment (Annex Table 0.2). However, unlike France or Spain, such employment acts as a stepping stone to more stable and regular work.

The limited changes in unemployment rates and ratios as well as contract types and transition speed between 2007 and 2014/2015 suggests that youth labor demand was not strongly affected by the recent crisis. 


\subsection{Employment-centered cluster}

Countries in the employment-centered transition cluster (e.g. DE, FR, NL) are characterized by selective and highly standardized education and training systems, with well-developed apprenticeship and national certification systems. The German education system's selectivity is clearly shown in the educational attainment data. Among the eight countries reviewed, Germany has the highest proportion of young people aged 20-24 with medium ISCED (70.7\%) and the lowest proportion with high ISCED (6.4\%), whereas France has high shares of youth with high ISCED, especially those aged 20-24 (28.8\%) (Annex Table 0.3).

Dual VET constitutes a core feature of the German education system, with apprenticeships providing the main form of VET at the upper secondary level (Eurofound, 2014). In the Netherlands, apprenticeships are slightly less prominent, whereas in France school-based VET still dominates (Eurofound, 2014). Employers are actively involved in defining the design and content of VET in Germany and the Netherlands, closely cooperating with VET providers (Eurofound, 2014). However, in France, there is insufficient cooperation between employers and educational institutions, especially within general secondary education. STW transitions in Germany and the Netherlands are generally efficient, especially for those with medium ISCED indicating well-established VET systems, which also contribute to both countries having the lowest NEET rates (Annex Table 0.2). High degrees of occupational specificity (Gangl, 2001, Brzinsky-Fay, 2007) and the strong involvement of relevant stakeholders (Eurofound, 2014; Gonzalez Carreras et al, 2015) in the German and Dutch training systems are important driving forces for smooth STW transitions.

Youth unemployment rates in Germany and the Netherlands are the lowest among all countries reviewed. However, Dutch youth unemployment ratios for 15-24 year-olds are relatively high. This shows why it is important to take both indicators into account. For example, the Polish unemployment rate for 15-24 is almost twice as large as the Dutch rate. Nevertheless, the unemployment ratio for 15-24 in Poland is lower because more young people in the Netherlands are active in the labor market. This discrepancy in the share of active young people in the labor market between countries is especially strong for those aged 15-24 and much less important for those aged 25-29 who are less affected by differences in educational systems (Annex Table 0.1).

Long-term unemployment rates are rather average in Germany and the Netherlands (Annex Table 0.2). The difference in short- and long-term unemployment rates is due to the fact that short-term unemployed people tend to participate over-proportionally during periods of economic recovery, as is the case in Germany or the Netherlands. The situation in France is more difficult because both short- and long-term unemployment rates are high.

Germany and the Netherlands have strict EPL for permanent employment, while their EPL for temporary employment is well below the OECD average. In France, EPL for permanent and temporary employment is high. Despite these EPL differences, temporary employment for 15-29 year-olds was above the EU average in all three countries in 2015. However, it must be noted that half of all fixed-term contracts relate to apprenticeships in Germany, with a much better transition probability compared with France (Annex Table 0.2). Segmentation is also predominant in France, not only for disadvantaged but also qualified youth (Eurofound, 2014).

Differences in ALMPs between France, Germany and the Netherlands are related to their different educational systems and general economic performance. The Netherlands has traditionally high ALMP spending (e.g. the EU's highest ALMP spending in 2014), with a focus on mediation and re-employment or reintegration, especially for the most vulnerable groups (Bekker et al. 2015). Wage subsidies also play a crucial role in France and the Netherlands in terms of helping young people to acquire work experience. In Germany, basic training and assistance for less educated youth is also gaining importance due to the favorable labor market situation. Thus, the specific focus of ALMPs not only depends upon the general orientation of a particular cluster, but also a country's current economic situation. 
Comparing unemployment rates and ratios as well as contract types and transition speed between 2007 and 2014/2015 suggests that youth labor demand has been negatively affected by the recent crisis in the Netherlands and even more strongly in France, leading to lower and more unstable employment. Conversely, Germany has experienced higher youth labor demand due to its exceptionally favorable economic situation, with improved labor market conditions in 2015 compared to 2007.

\subsection{Liberal cluster}

Liberal youth transition regimes - exemplified by the UK - are characterized by a comprehensive education system, as well as high flexibility and fragmentation in post-compulsory education. VET delivery models are not standardized, while VET is accessible through school-based programs combining academic study with vocational elements, broad vocational programs or specialist occupational programs delivered at both school and the workplace.

VET focuses rather narrowly on delivering particular occupational skills, albeit with less specialization and lower quality standards than in the employment-centered model. Indeed, the UK's VET provision has been criticized as being too focused on basic skills and relatively low-level qualifications.

The liberal regime is also characterized by limited employer engagement in VET provision, with employers seeing themselves as 'customers' of the education system rather than partners (Tassinari et al, 2016). In fact, the de-coupling of the education system and labor market - as well as the lack of joint delivery or co-design of VET - has made skill mismatch a reoccurring concern. A significant minority still leaves secondary education without the necessary skills and qualifications to compete in the labor market.

Recent reforms in the UK - especially the Apprenticeship Trailblazer reforms - have attempted to increase employer involvement in designing and delivering apprenticeship standards (Hadjivassiliou et al, 2015a). Although the UK's policy intention is to affect a major change in the STW transition pattern by expanding apprenticeships, it is too early to assess whether this will lead to a permanent path shift.

The UK's educational attainment data reflect this cluster's distinctive feature, namely VET's relatively minor role. Indeed, 'academization' is highest for both 20-24 and 25-34 year-olds among all countries reviewed (Annex Table 0.3). For this very reason, employability is an important concern for the UK's youth-related policy, as reflected in the work-first focus of youth-related ALMPs.

The liberal cluster is characterized by low EPL: the UK's EPL is one of the lowest in the OECD, resulting in a less segmented labor market. However, it also helps give rise to hyper-precarious forms of employment such as zero-hours contracts, where working hours are set by employer demand, leading to unpredictable/unstable income. This transfer of business risk from employer to employee is especially prevalent among young people; indeed, 36\% of people employed on zero-hours contracts are aged 16-24 (ONS, 2016).

ALMPs are not specifically targeted at young people, apart from some flagship initiatives - such as the Youth Contract - targeting unemployed youth. Contrary to the other clusters, subsidies play a minor role, with interventions being mainly focused on supply-side measures (Hadjivassiliou et al, 2015a).

Youth unemployment and long-term unemployment rates (Annex Table 0.1) are comparatively low, achieved - as explained above - by low EPL. Whereas this reduces rigidities that are harmful for STW transitions, it also creates unstable working conditions: the employment rate three years after competing education tends towards the average for all education levels through high job turnover (Annex Table 0.2) (Hadjivassiliou et al, 2015). In general, the UK is characterized by fast but unstable STW transitions. Due to low EPL for permanent contracts, temporary contracts are rarely used (Annex Table 0.2). The UK's labor market seems to have performed relatively well in the recent crisis, although long-term unemployment remains considerably above the pre-crisis level and is recovering more slowly than short-term unemployment. 


\subsection{Mediterranean cluster}

The Mediterranean model - represented by Spain - is characterized by non-selective and comprehensively structured compulsory education systems, albeit with relatively low-quality, under-developed VET and comparatively high early school leaving (ESL) rates (Eurofound, 2014). The structure of educational attainment reflects this cluster's non-selective nature of educational system and weak VET role. Indeed, the Spanish education system is rather polarized with the lowest level of ISCED 3-4 attainment for those aged 2024 and especially for those aged 25-34 (Annex Table 0.3).

Education and training are centrally standardized and the incidence of apprenticeships is comparatively low, although there have been efforts to make VET more flexible and closely aligned to employers' skill needs (González-Menéndez et al, 2015a).

The distinctive characteristics of the Mediterranean model include the relatively high EPL levels, especially for permanent employees, as well as the relatively ungenerous benefits system. The Spanish labor market is highly segmented, with a high incidence of temporary employment especially among youth, due to the gap in EPL between highly regulated permanent contracts and deregulated fixed-term ones. However, while past reforms only reduced protection at the margin and thus increased segmentation, recent reforms also deregulated EPL for permanent contracts (González-Menéndez et al, 2015a).

The employment rate three years after completing education in Spain is the lowest among all countries reviewed. In particular, individuals with medium or high educational attainment face comparatively low employment rates (Annex Table 0.2). This cluster's institutional features tend to generate the greatest difficulties for labor market entry, due to large proportions of low-skilled entrants, comparatively high EPL for permanent jobs and the absence of a comprehensive social safety net (Gangl, 2001; Brzinsky-Fay, 2007). This makes STW transitions complex, lengthier and unstable.

ALMPs are relatively under-developed, with challenges arising from the weak institutional capacities of the Public Employment Services (PES), although improving ALMP delivery and strengthening activation constitute some of the main areas of recent policy intervention. Spanish ALMPs seek to improve young people's skills or provide them with work experience (González-Menéndez et al, 2015). An increase in the supply of work experience and/or job placements for young people is pursued through hiring subsidies that reduce non-wage labor costs.

Institutional factors are overshadowed by a lack of labor demand in Spain as the main factor explaining poor performance in youth transitions. Indeed, the Spanish labor market was one of the most adversely affected by the recent crisis, which is why every indicator must be seen in the light of extremely low levels of youth labor demand.

Consequently, Spain has the highest youth unemployment rate and ratio in 2015. Similar to Poland, the discrepancy between these indicators is high for those aged 20-24, as well as being much higher than in 2007. Thus, young people seem to postpone graduation due to the economic downturn (Annex Table 0.1). Additionally, long-term youth unemployment, the NEET rate and temporary employment are the highest in 2015 among the eight countries (Annex Tables 0.1 and 0.2). However, aside from temporary employment, these indicators were close to or below the EU average in 2007, indicating how labor demand fluctuations can change our assessment of STW transition regimes.

\subsection{Post-socialist/transition cluster}

In both Estonia and Poland, compulsory education systems are comprehensive, with post-compulsory general education remaining a more popular choice than vocational education, partly due to VET's low reputation and excessive rigidity (Ślezak and Slopa, 2015). In 2015, Poland had the lowest levels of low-qualified youth and the highest rate of medium ISCED attainment among those aged 20-24, partly because compulsory education 
lasts until 18. Educational attainment in Estonia is closest to the EU average (Annex Table 0.3). In both countries, NEET rates were also slightly below the EU average for those aged 15-24. Whereas NEET rates for 25-29 year-olds are close to the EU average in Poland, they are five percentage points below average in Estonia.

VET in Poland is mostly school-based, whereas in Estonia it involves a greater share of company-based training, albeit still within a school-based delivery model. In Estonia, apprenticeships account for only about $2 \%$ of students, while they are marginally more common in Poland (European Commission, 2015a). Employer involvement in VET is relatively low, although there have recently been efforts to increase employer engagement in VET. The linkages between the education system and labor market are also weak, resulting in considerable skills mismatch.

Similar to the UK, low incidence of work-based training increases the need for ALMPs, which enhances youth employability, especially by providing financial incentives for employers to hire young people. Both countries also focus on specializing and standardizing educational paths in line with labor market needs (Eamets and Humal, 2015; Ślezak and Szopa, 2015). In both countries, the policy instruments used to support the STW transition include training and/or employment subsidies to increase the supply of work experience placements. Nevertheless, differences exist between the two: whereas ALMPs in Estonia mainly concentrate on less educated youth, in Poland they also target highly qualified young people, given that graduate unemployment is quite high.

Estonia has relatively low EPL for permanent and relatively high EPL for temporary employment. However, in Poland, EPL is much stricter for permanent rather than temporary employment, making the latter more attractive to employers: whereas the incidence of temporary employment in 2015 among 15-29 year-olds is extremely high in Poland (54\%), it is the lowest (8\%) in Estonia among the countries reviewed (Annex Table $0.2)$.

Inflexibility in terms of institutional rigidity - which hampers adjustments to labor market changes - is one major impediment to smooth STW transition in Poland (Ślezak and Szopa, 2015). The youth employment rate within three years after completing education corresponds to the EU average in both countries, when considering all education levels together. However, educational attainment in Poland is much more important than in Estonia. Those with the lowest levels of educational attainment there face similar labor market entry barriers as in France (Annex Table 0.2). This relates to the Polish educational system, which produces the lowest proportion of young people with low educational attainment who may face a crowding-out effect by higher-educated youth, leading to over-qualification. (Annex Table 0.3). In 2015, Polish unemployment and long-term unemployment rates were close to the EU average. Estonian unemployment rates were among the lowest in the EU in 2015, although they had dramatically increased during the first period of the crisis. Both countries have recovered rather well from the recent crisis, as unemployment rates in 2015 are similar to those in 2007 and long-term unemployment rates have considerably declined (Annex Table 0.1). 


\section{Institutions in Flux: How are Youth Transition Regimes Changing?}

The Great Recession and its aftermath have hit young people particularly hard across the EU and in most of the countries reviewed. This has resulted in (i) a dramatic rise of youth unemployment in most countries; (ii) lengthier, unstable and non-linear STW transitions; (iii) a deterioration of youth employment quality combined with greater precariousness; (iv) increased discouragement and labor market detachment; and (v) greater labor market vulnerability of disadvantaged youth such as the low-skilled, migrants and the disabled. While recession-related economic deterioration and subsequent job-poor recovery account for such developments, these are also rooted in persistent structural deficiencies such as poorly performing education and training systems, segmented labor markets and low PES capacity. As shown in Section 3, the degree to which these adversely affect young people considerably varies between and even within clusters. However, a general deterioration in the length and quality of STW transitions is observed in all five clusters, albeit its extent regarding the five indicators mentioned above is variable.

Against this backdrop, following the Great Recession it is unsurprising that considerable policy action at the EU and national levels has focused on reforming the institutional arrangements that structure the STW transition process. In Section 4.1, we discuss some of the most notable institutional changes observed across the eight countries in the five clusters reviewed. These cover the period 2007-2015 and were introduced either relatively early during the crisis or immediately after or as part of the YG implementation (2013 onwards). In view of this changing policy landscape, some of the characteristics of each regime are in a state of flux, albeit more in some clusters (e.g. Mediterranean) compared with others (e.g. universalistic). Moreover, as discussed below, competing trends of convergence and persisting divergence in different policy areas across clusters appear to be emerging. The implications of these ongoing processes of institutional change for the coherence and applicability of the existing typologies of youth transition regimes as well as the quality of STW transitions are assessed in Section 4.2.

\subsection{Trends in institutional change and convergence}

Between 2007 and 2015, there has been change in governance structures, institutional frameworks and actual policies and mechanisms associated with each STW transition regime across all countries in the five clusters. In many countries, the introduction of the YG in 2013 has acted as a catalyst for structural reforms. These institutional and policy changes are likely to affect the way in which the STW transition is structured in individual countries and their respective clusters. We identify five areas where institutional change has been especially prominent in 2007-2015: the strengthening of ALMPs and PES capacity, the decentralization and localization of governance and delivery of youth employment policy; targeting of NEET policies, reforms of VET and apprenticeships and EPL reforms. Below, we discuss the parallel trends of convergence and persisting divergence in these policy areas across clusters.

\section{Strengthening of activation and PES capacity}

The institutional field of ALMPs has been the focus of substantial policy innovation between 2007 and 2015, as well as being subject to some contradictory trends regarding the trajectory of change. Countries in all five clusters have intervened to strengthen their ALMPs and related infrastructure, most notably PES, although this has not been matched overall by an increase in available resources.

The YG - the EU's flagship youth employment program - has arguably been a potentially important driver of change in this area. Its implementation combines measures to help young people into employment in the short run, with comprehensive structural reforms aimed at introducing systemic change in the structuring of STW transitions. These include introducing properly designed activation policies, well-functioning PES, cross- 
sectoral partnerships, multi-agency working and outreach measures aimed at NEETs and disengaged youth, as well as effective VET and apprenticeship policies (European Commission, 2015b).

In countries such as Estonia, France, Poland and Spain, the YG implementation has involved PES restructuring to provide young people with individualized support, foster better links with both employers and education and training providers and adopt a more targeted and pro-active approach towards supporting NEETs (European Commission, 2015b; González-Menéndez et al, 2015a). For example, it seems that the YG has improved the Spanish PES capacity to play a more active role in addressing youth unemployment (GonzálezMenéndez et al, 2015a).

The countries reviewed have also introduced new or strengthened existing ALMPs and introduced changes in their activation models. In some cases, this emanated from the YG's focus on properly designed activation policies, while in others such reforms were enacted independently. For example, the YG's specific focus on young people's integrated STW transitions represents a departure from Estonia's traditional lack of labor market policies targeted at youth. As such, it arguably represents a 'new way of doing things', especially by focusing on increasing the combined effect of different measures and vulnerable youth (Eamets and Humal, 2015). Focusing even more on early intervention and activation, Sweden's government has reinforced the Swedish YG with a gradual introduction of a 90-day guarantee (Wadensjö, 2015; Forslund, 2016). Moreover, there is much greater focus on closer cooperation between central and local government (and PES) to ensure that youth-related ALMPs have greater impact at the local level (Forslund, 2016).

Independent of the YG, the UK also implemented a raft of youth-related ALMPs such as the Youth Contract, introduced in 2012 with a strong focus on early activation and/or education and training. Similarly, in the Netherlands, there has been a distinct reinforcement of activation combined with severe restrictions to benefit access for youth aged 18-27 following the 2009 Investment in Youth Act (Eichhorst and Rinne, 2014).

Although the YG concept - including its focus on early, personalized and integrated interventions - has been welcomed, its implementation across the EU has unsurprisingly been patchy and uneven (Eurofound, 2015; Bussi, 2014). Moreover, the EU funds earmarked for the $Y G$ are seen as inadequate for the effective implementation of YG-related reforms, including those targeted at NEETs (ILO, 2015; Dhéret and Morosi, 2015; Eurofound, 2015). The uneven absorption capacity of EU funds across the EU - especially at the regional level - combined with a lack of mobilization of some Member States has cast further doubt on their ability to successfully implement the YG (ETUC, 2016; Bussi, 2014).

These examples point to the emergence of a partly contradictory trend, where changes in policy design to strengthen ALMPs' effectiveness have not been matched by adequate increases in capacity. With the exception of Germany and - to some extent - Sweden, in most other countries reviewed (e.g. EE, ES, NL, PL, UK) such efforts have not been accompanied by an increase in funding commensurate to the magnitude of youth unemployment. For example, in Spain - where youth unemployment rose dramatically during the Great Recession - substantial fiscal consolidation linked to its austerity program have led to PES recruitment freezes and thus affected PES capacity to help increasing numbers of young job-seekers (European Commission, 2016g). Likewise, following the crisis and ensuing higher unemployment, the Polish PES did not receive additional funds (Ślezak and Szopa, 2015). During the crisis, Estonia was one of the countries with the most severe austerity measures with obvious adverse implications for PES capacity (Eamets and Humal, 2015).

Moreover, while this focus on PES capacity marks potential convergence regarding policy objectives across clusters, PES' ability to actually strengthen their links and cooperation with both employers and education and training institutions is highly variable and often rather limited or even missing (Dhéret and Morosi, 2015). In both Spain and France, there has been concern about the PES capacity to adequately service the large number of unemployed young people (European Commission, 2016b and 2016e). Concerns about capacity in the delivery of ALMPs extend beyond PES. For example, in Sweden there are concerns that reinforced municipal youth-related activation responsibility has not been accompanied by a commensurate re-alignment between 
municipalities and centrally financed PES of financial incentives for ALMPs, thus limiting the municipalities' outreach capacity (European Commission, 2016d).

\section{Decentralization and devolution of responsibility}

The extent to which major changes regarding governance structures and/or institutional frameworks underpinning STW transitions were implemented as a result of the YG varied across contexts, largely depending on the pre-existing institutional setup. However, across clusters we observe convergence in terms of greater decentralization and devolution of responsibility for supporting effective STW transitions at the local level, combined with greater autonomy and flexibility in addressing the specific needs of young people, especially NEETs.

In Germany and the Netherlands, where the YG can be considered an up-scaling of existing measures, change has mainly occurred in the form of the ongoing decentralization and localization of the responsibility for supporting STW transitions from the national to local level. The objective is to enhance the cooperation and cross-agency working of local partnerships and provide more integrated services to disadvantaged youth (Düll, 2016). In the Netherlands, since 2015 the responsibility for delivering employment and youth care services has shifted to local authorities (Bekker et al, 2015a and 2015b). In Germany, municipal-level initiatives such as the Jugendberufsagenturen in Hamburg have developed effective local models of one-stop shops offering integrated, multi-agency services to young people (Gehrke, 2015).

Likewise, while municipalities (and the state) have always been the main actors for youth-related policies in Sweden (Wadensjö, 2015), their activation responsibility has been strengthened since January 2015, whereby they are now directly responsible for activating early school leavers and following up NEETs for targeted support (Forslund, 2016). Devolution is also occurring in the UK, where local authorities now have formal responsibility for tracking young people's participation in education or training and supporting NEETs in finding suitable training (Hadjivassiliou et al, 2015a).

Moreover, there seems to be convergence - sometimes instigated by YG implementation rules - in setting up broader stakeholder partnerships to offer integrated services to young people, especially youth at risk. Most countries are improving or setting up new governance structures such as stronger partnership working arrangements and broader stakeholder engagement to address fragmentation in youth-related policies (ILO, 2015; Eurofound, 2015). For example, the introduction of the YG in Spain has led to better PES coordination between different levels of government and improved inter-regional cooperation (European Commission, 2016g), while providing a new framework for policy transfer across several government levels (GonzálezMenéndez et al, 2015). Nonetheless, such broader stakeholder involvement and partnership working is not always easy to achieve in national or local contexts with no tradition, structures or mechanisms for crossagency collaboration (e.g. France and Poland).

Both Estonia and France have strengthened partnership working across government agencies (European Commission, 2016a and 2016b). For example, Pôle emploi (French PES) and missions locales (local PES for youth) are negotiating an agreement to improve their partnership working and provide adequate services to young people (European Commission 2016b). However, the extent to which this attempt will succeed is questionable, since the coordination of actors has historically been problematic within the fragmented French STW transition system, which lacks an overarching coordinating structure and integrative logic (European Commission, 2016b; Smith et al, 2015). Similarly, in Poland the YG has stimulated enhanced cooperation between local-level employment offices (Poviat) and a wide range of organizations such as academic career centers, local Voluntary Labor Corps (OHP) units, social welfare centers or schools (Weishaupt, 2014). However, effective cooperation between PES and OHP regarding youth-related ALMPs remains a challenge (European Commission, 2016c).

Moreover, early indications of the YG implementation show that social partner and youth organizations' involvement has been very limited in most countries (Eurofound, 2015; Dhéret and Morosi, 2015). 


\section{Targeting of NEET policies: addressing low-skilling and early school leaving}

Another common pattern across clusters has been an increased focus on targeting and diversifying youth transition policies: in particular, there is a stronger focus on NEETs, early school leavers and other youth-atrisk groups such as the low-qualified, those from an ethnic minority and/or migrant background as well as those from a lower socio-economic and/or disadvantaged background.

Education-related reforms have focused on addressing low educational attainment, a key determinant of becoming a NEET. Policy interventions across all clusters have focused on reducing ESL to ensure that young people leave school with at least an upper secondary education qualification (Hadjivassiliou, 2016), which has proved to be the minimum labor market entry requirement (European Commission, 2015a). For example, the 2013 education reform (Ley Orgánica para la Mejora de la Calidad Educativa/LOMCE) in Spain seeks to reduce ESL by allowing those aged 15-17 to enroll in Basic Professional Training to obtain the upper secondary school qualification and eventually access higher-level training (González-Menéndez et al, 2015a and 2015b). Likewise, given the large share (around 25\%) of youth who have not successfully completed upper secondary education, in 2015 Sweden introduced so-called 'education contracts' to encourage unemployed young people aged 20-24 to complete their upper secondary education (Wadensjö, 2015; Forslund, 2016).

Across all clusters, there has also been an increased focus on targeting NEETs through either training and education or activation measures, rehabilitation programs, more integrated services and outreach activities to identify, register and (re)engage NEETs. This is crucial given the large numbers of NEETs who are not registered with PES and cannot access YG-related and other supportive interventions. However, although many countries - including Spain and Germany - have set up online outreach tools, engaging unregistered, 'hardest to reach' youth through grassroots-j actions (e.g. street outreach work) and multi-agency working remains less common (Eurofound, 2015; Hadjivassiliou, 2016). This constitutes a serious limitation, as online outreach tools (e.g. using Facebook and other social media and/or designated online platforms/portals to reach out to NEETs) cannot replace face-to-face interaction, especially with youth with more complex problems (ICF, 2015).

Overall, it is fair to say that in many cases the YG has provided an additional impetus in focusing on NEETs, although again it is too early to gage the effectiveness of certain innovations.

\section{VET and apprenticeships}

There appears to be tentative convergence across clusters, including in the institutional area of VET and apprenticeships, although changes may be confined to policy objectives rather than actual outcomes. VET including apprenticeships - is increasingly considered key to lowering youth unemployment and facilitating STW transitions across the EU. Consequently, there has been an effort to reform or strengthen the role of VET/apprenticeships in STW transitions across all five clusters. The extent of change seems to be more farreaching - at least in terms of policy intention - in the Mediterranean cluster, where there is a concerted effort to expand apprenticeships and other forms of VET (González-Menéndez et al, 2015a; European Commission, 2015a). For example, Spain has recently embarked upon a major educational reform to improve the quality of education - including VET - and the links between its education system and the labor market. The Royal Decree $1529 / 2012$ laid foundations for the gradual introduction of the dual training principle in Spain's VET and sought to foster the greater participation of companies in VET (González Gago, 2015; González-Menéndez et al, 2015a). Moreover, the recent educational reform introduced more vocational pathways in lower secondary education and a new two-year VET module to address ESL (González Gago, 2015).

Similarly, since 2013 the UK (liberal cluster) has been implementing a major VET and apprenticeship reform to address long-standing issues around VET and its role in STW transitions. The Apprenticeships Trailblazers reforms attempt to put employers at the heart of the apprenticeship system and - as such - represent a potential paradigm shift within the UK context (Tassinari et al, 2016). The reforms aim to promote VET and associated career pathways as a high-quality option and expand apprenticeship take-up (Hadjivassiliou et al, 2015a). 
Similar VET/apprenticeship reforms have been introduced in Estonia (2013), Sweden (2014) and France (2013 and 2014).

Hence, VET and apprenticeships may potentially become more important STW transition mechanisms, even in the liberal (UK) and the Mediterranean (ES) clusters, where they have traditionally been under-developed. However, introducing apprenticeships/VET reforms at the policy design level is not sufficient to bring about deep-seated institutional change. This requires a change in the attitude of training providers and employers and increased partnership working between the two, which is not easily achieved in countries lacking such a tradition of cooperation like in France, Poland, Spain and the UK (Eurofound, 2015; Smith et al, 2015; Slezak and Szopa, 2015; Hadjivassiliou et al, 2015b).

VET reforms also require strong and unequivocal employer support in terms of offering an adequate supply of quality placements and associated training (Eichhorst, 2015). Change is also required in the attitude of young people and their families, whereby apprenticeship/VET is not seen as a second-best option (Eichhorst, 2015). Nonetheless, VET still suffers from a rather poor image in the Mediterranean (ES), post-socialist (EE, PL) and liberal (UK) clusters (González-Menéndez et al, 2015a; Eamets and Humal, 2015).

There is also concern about the education and training systems' ability to quickly adapt in line with the new VET/apprenticeship reforms to deal effectively with the current cohort of unemployed youth, as well as the gap between employer demand and the VET system's ability to respond satisfactorily (Eurofound, 2015). All such factors may act as barriers to deep institutional change in this policy area.

\section{Flexibilization of youth labor markets \& EPL reforms}

Finally, the issue of persistent labor market segmentation is common across all five clusters, although the trajectory of change seems to be one of convergence towards greater 'flexibilization' in youth labor markets across clusters, rather than greater security.

EPL reforms have focused on achieving a better balance in protection between those on permanent and temporary contracts, thus reducing existing dualisms. For example, in the Netherlands, EPL changes since July 2015 seek to - inter alia - strengthen the position of those on temporary contracts (Bekker et al, 2015b). Similarly, in Spain, following the 2010 and 2012 labor market reforms, the deregulation of EPL for permanent contracts has reduced the dualism between temporary and permanent employment protection (GonzálezMenéndez et al, 2015b). The Estonian Employment Contracts Act (2009) introduced major reforms aimed at increasing labor market flexibility. In France, EPL changes - which have proved highly controversial and politically difficult - have been more limited but have also sought to reduce labor market dualism.

However, it is rather too early to gage the impact of these changes on youth labor markets, especially against a backdrop of limited labor demand in some of the countries examined. More worryingly, existing evidence suggests that the share of temporary contracts among youth has even increased in countries that have deregulated EPL during the crisis, such as France and Spain (Eichhorst et al, 2016). The available evidence suggests that attempts to lower EPL for permanent contracts in highly-dualized labor markets (e.g. Spain, France) are likely to result in worsening working conditions and more unstable employment, rather than facilitating STW transitions (Eichhorst and Rinne, 2014; González-Menéndez et al, 2015a and 2015b). Even the traditionally better performance of some STW regimes seems to come under question, with increasing rates of temporary, precarious employment among young people in countries like the Netherlands, thus pointing to a potential convergence towards lower quality of transitions across the board.

\subsection{Assessing the impact of institutional change on youth transition regimes}

As highlighted above, ongoing processes of institutional change in the targeting, design and governance of ALMPs, the status of VET systems and the design of EPL institutions are leading to a reconfiguration of 
European youth transition regimes. The five convergence trends in the trajectory of policy change during the crisis described above are accompanied by persisting divergence in institutional and fiscal capacity across countries that - together with dynamics of institutional path dependency - affect the depth and effectiveness of reform implementation and thus raise doubts about the possibility of substantial institutional change occurring in the short run.

Nonetheless, our analysis suggests that the STW transition regimes as defined by the Pohl and Walther's typology may be in a state of flux as a result of policy developments during the recent crisis. Rubery's (2011) 'regime hybridization' concept is relevant here to capture the nature of the ongoing institutional changes affecting the structure of youth transition policy regimes in Europe. Indeed, recent policy developments are blurring the distinctions between regimes and potentially altering their underlying logic structuring youth transitions in each cluster. Countries across all regimes have recently adopted reforms in regulation and policy instruments that do not belong to their 'traditional' institutional legacy as captured by Pohl and Walther's (2007) typology. Furthermore, a tendency towards the greater liberalization of employment regulation has been accompanied by increased policy activity in 'new' areas - such as ALMPs - to address existing gaps in support and protection, in line with the trajectory identified by Rubery (2011) for European welfare regimes as a whole.

For example, reforms of VET and apprenticeship systems have achieved prominence in countries belonging to the liberal and Mediterranean clusters, where these instruments have traditionally been secondary in importance, while at the same time the sustainability and effectiveness of VET has faced challenges in the employment-centered and universalistic cluster countries, where it has traditionally been more established. The increased focus on 'supportive' and targeted ALMPs - traditionally characteristics of the 'universalistic' cluster - is now spreading to countries where such instruments were considerably less developed, such as those belonging to the Mediterranean and post-socialist cluster, largely as a result of the policy convergence process driven by the YG. At the same time, processes of labor market flexibilization are changing the institutional architecture of employment regulation towards greater liberalization across the board, including in countries traditionally characterized by entrenched dualisms in protection (e.g. those belonging to the Mediterranean or employment-centered clusters).

Although developing revised typologies was not an objective of our analysis, our findings show that it is necessary to consider institutional configurations and 'clusters' as dynamic, as well as continuing to devote attention to processes of institutional and structural change that may be altering the underlying logic of distinct youth transition regimes over time.

Although the limited number of countries in our sample did not allow us to systematically explore the internal 'coherence' of the different youth transition regimes outlined by Pohl and Walther (2007), our analysis has shown that considerable variation exists across countries, even within clusters that share common underlying logics of institutional configuration. This suggests that while the 'youth transition regime' concept can act as a useful heuristic, analytical device, generalizations at the cluster level in terms of performance are inherently difficult.

In terms of impact on performance, most reforms introduced in the aftermath of the Great Recession are very recent, which makes it difficult to assess the extent to which they will affect future positive change in the quality and speed of STW transition and thus help to tackle performance challenges associated with each regime. However, some preliminary remarks can be made. In the universalistic cluster, where the main challenge arises from the difficult labor market integration of specific groups of disadvantaged youth, current efforts to improve the speed and targeting of activation measures may prove helpful. In the employmentcentered and Mediterranean clusters, where a key youth-related challenge arises from high levels of labor market segmentation, the current policy trend of greater labor market flexibilization may actually be counterproductive in ensuring fast and secure transitions. Indeed, it has already resulted in higher levels of temporary and precarious employment - at least in the short run (Eichhorst et al, 2016). 
Increasing PES capacity and strengthening ALMPs is another fundamental area of intervention to help disadvantaged youth across clusters, especially in the Mediterranean and post-socialist clusters. Likewise, reforming VET to increase linkages between education and the labor market could be helpful to address the skills mismatch pervasive in the Mediterranean and liberal clusters. However, as discussed above, the depth of policy change in these areas remains limited due to dynamics of institutional path dependency and the low availability of resources for effective implementation. The overall emerging picture is thus one where policy changes aimed at strengthening supportive policy instruments - such as expanding ALMPs and PES capacity and strengthening VET systems - are currently limited in their reach and potential effectiveness. At the same time, the trends of the liberalization and deregulation of protective institutions - such as EPL - contribute to making young people's STW transitions potentially more unstable, at least in the short run.

\section{Conclusions}

Our comparative analysis has shown that countries' institutional configurations considerably matter in shaping the structure of young people's STW transitions and mediating the impact of the Great Recession on youth unemployment. Drawing upon Pohl and Walther's concept of 'youth transition regime' (2007), we have assessed the performance of countries belonging to different clusters regarding the speed, ease and quality of STW transitions. The divergence in performance between countries belonging to different regimes - which had already started in 2007 and accelerated since 2009 (Boeri and Jimeno, 2015) - shows the important role of institutional arrangements in shaping STW transitions, especially in the fields of employment regulation, education and training and ALMPs.

In terms of transition mechanisms, in line with existing evidence, well-integrated VET systems with strong employer involvement and clear labor market connections and supportive ALMPs have emerged from our analysis as important institutional characteristics that have historically enabled the comparatively better performance in STW transitions of the universalistic (SE) and employment-centered (DE, NL) clusters. Therefore, it is unsurprising that recent post-crisis policy interventions introduced by European countries including the YG initiative - have focused on strengthening these two institutional areas. In VET, the focus has primarily been on expanding apprenticeships as a transition route and increasing linkages between training systems and the labor market by enhancing employer involvement. In ALMPs, policy intervention has focused on improving PES capacity and diversifying existing activation measures to provide more personalized support to unemployed youth, including NEETs. Given the well-documented 'scarring' effects of NEET status, this renewed NEET focus is welcome, as is the tailoring of responses across clusters in recognition of the NEET population's heterogeneity (see Zuccotti and O'Reilly, Mascherini and Ledermaier this volume).

These areas of policy change could be seen as a potential sign of convergence across regimes in terms of their underlying logic of STW transitions. However, the extent to which such policy changes can become embedded in other contexts crucially depends on existing institutional and coordination capacity as well as the availability of resources. Indeed, VET systems are complexly interwoven within the broader institutional fabric, with the evidence suggesting that the potential for far-reaching change may be limited due to dynamics of institutional path dependency; for example, the lack of established mechanisms for social partner and employer engagement and coordination. Likewise, the absence of pre-existing institutional infrastructures of coordination in numerous countries threatens the success of attempts to improve PES capacity and establish effective partnership working between different agencies to engage hard-to-reach youth.

Resource limitations - both fiscal and in terms of actors' capacity - also act as a barrier against more deepseated institutional change, potentially making the transfer of 'good practice' across regimes inherently difficult. Despite EU funding, in most cases reforms are being introduced against a backdrop of tight public finances, austerity and spending cuts, which undermines the effective implementation of policies such as the 
expansion of ALMPs and PES capacity. Moreover, against a fragile economic recovery in many Member States - and even persistent flat-lining or recession in few - employer absorption capacity in providing training places (such as apprenticeships) (and jobs) to young people may be limited (Eurofound, 2015).

In line with existing evidence, employment regulation has also emerged from our analysis as a key factor affecting the quality and nature of STW transitions. Differential levels of EPL between temporary and permanent employment have led many countries - especially in the Mediterranean and employment-centered clusters - to entrenched labor market segmentation, with young people being increasingly confined to the labor market's temporary segment. Since 2010, many countries have tried to tackle segmentation by de-regulating permanent contracts (Eichhorst et al, 2016,). Despite being more pronounced in the most segmented countries such as France and Spain, this has also occurred in better performing ones such as the Netherlands. While reducing segmentation, excessive flexibility can lead to low employment quality and high precariousness, as the experience of the liberal and post-socialist clusters shows. The trend emerging from reforms implemented in the Great Recession thus seems to point towards greater labor market flexibilization, which is not promising in terms of ensuring that transitions are stable and secure in the long run. Balancing flexibility and security in youth labor markets represents a key outstanding challenge yet to be fully confronted in all clusters.

We would also like to emphasize that while our analysis has shown that institutional configurations are very important in shaping the structure, nature and effectiveness of STW transitions, the performance of countries and regimes is also significantly shaped by macro-economic trends, especially by levels of demand for youth labor. In a context where youth labor demand remains low, policy interventions solely focused on the supply side or encouraging flexibility will necessarily remain limited in their effectiveness. In general, our analysis has shown that the institutional configurations of STW regimes in Europe are currently 'in flux', which makes the validity and applicability of established typologies - such as Pohl and Walther's (2007) - limited in the present historical phase due to ongoing dynamics of regime hybridization (Rubery, 2011). Current trends of emerging 'convergence' across clusters in the design of youth transitions policy instruments may alter the logic of transition systems across regimes in the long run, thus making a new conceptualization of youth transition regimes necessary. However, at present, this institutional change remains limited in terms of impact and superficial in terms of actual implementation. Differences in performance across regimes persist, with some faring better than others, although at the same time a common, worrying trend can be identified across clusters, comprising a progressive deterioration of the quality of youth transitions across the board, despite the positive policy intentions to strengthen and improve the efficacy of transition regimes. 


\section{References}

Bekker, S., van de Meer, M. and Muffels, R., (2015a). Barriers to and Triggers of Innovation and Knowledge Transfer in the Netherlands, WP4.1/NL, STYLE Working Papers, WP3.3/NL, CROME, University of Brighton, Brighton

Bekker, S., van de Meer, M., Muffels, R., and Wilthagen, A., (2015b). Policy Performance and Evaluation: Netherlands, STYLE Working Papers, WP3.3/NL, CROME, University of Brighton, Brighton

Boeri, T. and Jimeno, J. F., (2015). The Unbearable Divergence of Unemployment in Europe, CEP Discussion Paper No 1384

Brzinsky-Fay, C. (2007), 'Lost in Transition? Labor Market Entry Sequences of School-Leavers in Europe', European Sociological Review, Vol. 23, No. 4, pp. 409-422.

Bussi, M., (2014). The Youth Guarantee in Europe, ETUI

Dhéret, C. and Morosi, M., (2015). One Year after the Youth Guarantee: Policy Fatigue or Signs of Action?, European Policy Centre (EPC), Policy Brief,

Düll, N., (2016). How to Best Combine Personalised Guidance, Work Experience and Training Elements Targeted at Vulnerable Youth? - Practices and Lessons from Germany, Peer Review on 'The Guarantee for Youth', Paris, 7-8 April 2016

Eamets, R. and Humal, K., (2015). Policy Performance and Evaluation: Estonia, STYLE Working Papers, WP3.3/EE, CROME, University of Brighton, BrightonEichhorst, W., Marx, P. and Wehner, C., (2016). Labor Market Reforms in Europe: Towards More Flexicure Labor Markets?

Eichhorst, W., Wozny, F. and Cox, M., (2015). Policy Performance and Evaluation: Germany, STYLE Working Papers, WP3.3/DE, CROME, University of Brighton, BrightonEichhorst, W., (2015). 'Does Vocational Training Help Young People Find a (Good) Job?', IZA Paper,

Eichhorst, W. and Rinne, U., (2014). Promoting Youth Employment through Activation Strategies, ILO, Employment Policy Department, Employment Working Paper No. 163

European Commission, (2016a). Youth Guarantee Country by Country - Estonia

European Commission, (2016b). Youth Guarantee Country by Country - France

European Commission, (2016c). Youth Guarantee Country by Country - Poland

European Commission, (2016d). Youth Guarantee Country by Country - Sweden

European Commission, (2016e). Youth Guarantee Country by Country - Spain

European Commission, (2015a). Education and Training Monitor 2015

European Commission, (2015b). Youth Unemployment - European Semester Thematic Fiche,

Eurofound, (2015). Beyond the Youth Guarantee - Lessons Learned in the First Year of Implementation, Background Document prepared for the informal EPSCO meeting of 16-17 July 2015, Luxembourg

Eurofound, (2014). Mapping Youth Transitions in Europe

European Trade Union Congress (ETUC), (2016). Towards a Real and Effective Youth Guarantee in Europe,

Forslund, A., (2016). Strategies to Improve Labor Market Outcomes of Youth at Risk - The Swedish Experience, Country Paper presented at the High Level Learning Exchange on 'Designing and Implementing Effective Strategies to Support the Integration and Retention in the Labor Market of Youth at Risk', Stockholm, 18-19 February 2016 
Gangl, M., (2001). 'European Patterns of Labor Market Entry: A Dichotomy of Occupationalized versus NonOccupationalized Systems?', European Societies, Vol. 3, No. 4, pp. 471-494.

Gehrke, A. M., (2015). WP7 Case Study: Jugendberufsagentur (JBA) 'Nobody Should Be Lost'

Gonzalez Carreras, F. J., Kirchner Sala, L. and Speckesser, S., (2015). The Effectiveness of Policies to Combat Youth Unemployment, STYLE Working Papers, WP3.2. CROME, University of Brighton, Brighton

González Gago, E., (2015). Co-ordination and Interdisciplinary Work as Key Answers to the NEETs - Spain, Peer Review on 'Targeting NEETs - Key Ingredients for Successful Partnerships in Improving Labor Market Participation', Oslo, 24-25 September 2015

González-Menéndez, M. C., Mato, F. J., Gutiérrez, R., Guillén, A. M., Cueto, B. and Tejero, A., (2015). Policy Performance and Evaluation: Spain, STYLE Working Papers, WP3.3/ES, CROME, University of Brighton, Brighton

González-Menéndez, M. C., Guillén, A. M., Cueto, B., Gutiérrez, R., Mato, F. J. and Tejero, A., (2015). Barriers to and Triggers of Policy Innovation and Knowledge Transfer in Spain, STYLE Working Papers, WP4.1/ES, CROME, University of Brighton

Hadjivassiliou, K. P., (2016). What Works for the Labor Market Integration of Youth at Risk, Thematic Paper presented at the High Level Learning Exchange on 'Designing and Implementing Effective Strategies to Support the Integration and Retention in the Labor Market of Youth at Risk', Stockholm, 18-19 February 2016

Hadjivassiliou, K., Tassinari, A., Speckesser, S., Swift, S. and Bertram, C., (2015a). Policy Performance and Evaluation: United Kingdom, STYLE Working Papers, WP3.3/UK, CROME, University of Brighton, Brighton

Hadjivassiliou, K., Tassinari, A. and Swift, S., (2015b). Barriers to and Triggers of Policy Innovation and Knowledge Transfer in the UK, STYLE Working Papers, WP4.1/UK, CROME, University of Brighton, Brighton

ICF, (2015). Relevance and Feasibility of MLP Activity on Outreach Work with NEETs

ILO, (2015). The Youth Guarantee Program in Europe: Features, Implementation and Challenges, Working Paper No 4

Office for National Statistics (ONS), (2016). Contracts that Do not Guarantee a Minimum Number of Hours: September 2016

Pohl, A., and Walther, A., (2007). 'Activating the Disadvantaged - Variations in Addressing Youth Transitions across Europe', International Journal of Lifelong Education, 26:5, pp.533-553

Rubery, J., (2011). Reconstruction amid Deconstruction: Or Why we Need More of the Social in European Social Models, Work, Employment and Society, 25(4), 658-674Ślezak, E. and Szopa, B., (2015). Policy Performance and Evaluation: Poland, STYLE Working Papers, WP3.3/PL, CROME, University of Brighton, Brighton

Smith, M. Toraldo, L. M., and Pasquier, V., (2015). Barriers to and Triggers of Innovation and Knowledge Transfer in France, WP4.1/FR, CROME, University of Brighton, Brighton

Tassinari, A., Hadjivassiliou, K. and Swift, S. (forthcoming), 'Plus ça change...? Innovation and Continuity in UK Youth Employment Policy in the Great Recession', Social Policies, 2/2016

Wadensjö, E., (2015). Policy Performance and Evaluation: Sweden, STYLE Working Papers, WP3.3/SE, CROME, University of Brighton, Brighton 
Weishaupt, T. J., (2014). Central Steering and Local Autonomy in Public Employment Services, Analytical Paper, PES-to-PES Dialogue 


\section{ANNEX}

Table 0.1 Unemployment Rate, Long-Term Unemployment Rate, Unemployment Ratio - 2007 and 2015 (\%)

\begin{tabular}{|c|c|c|c|c|c|c|c|c|c|c|c|c|c|c|c|}
\hline \multirow[t]{4}{*}{ Country } & \multicolumn{7}{|c|}{ Unemployment Rate } & \multicolumn{4}{|c|}{$\begin{array}{c}\text { Long-Term } \\
\text { Unemployment Rate }\end{array}$} & \multicolumn{4}{|c|}{ Unemployment Ratio } \\
\hline & \multicolumn{4}{|c|}{$15-24$} & \multicolumn{3}{|c|}{$25-29$} & \multicolumn{2}{|c|}{$15-24$} & \multicolumn{2}{|c|}{$25-29$} & \multicolumn{2}{|c|}{ 15-24 } & \multicolumn{2}{|c|}{$25-29$} \\
\hline & \multicolumn{2}{|c|}{2015} & \multicolumn{2}{|c|}{2007} & \multicolumn{2}{|c|}{2015} & $\begin{array}{c}200 \\
7\end{array}$ & $\begin{array}{c}201 \\
5\end{array}$ & $\begin{array}{c}200 \\
7\end{array}$ & 2015 & $\begin{array}{c}200 \\
7\end{array}$ & 2015 & $\begin{array}{c}200 \\
7\end{array}$ & 2015 & $\begin{array}{c}200 \\
7\end{array}$ \\
\hline & Total & $\begin{array}{l}\text { Wome } \\
\mathrm{n}\end{array}$ & $\begin{array}{l}\text { Tota } \\
1\end{array}$ & $\begin{array}{l}\text { Wo } \\
\text { men }\end{array}$ & $\begin{array}{l}\text { Tota } \\
1\end{array}$ & $\begin{array}{l}\text { Wome } \\
\mathrm{n}\end{array}$ & $\begin{array}{l}\text { Tota } \\
1\end{array}$ & $\begin{array}{l}\text { Tota } \\
1\end{array}$ & $\begin{array}{l}\text { Tota } \\
1\end{array}$ & $\begin{array}{l}\text { Tota } \\
1\end{array}$ & $\begin{array}{l}\text { Tota } \\
1\end{array}$ & $\begin{array}{l}\text { Tota } \\
1\end{array}$ & $\begin{array}{l}\text { Tot } \\
\text { al }\end{array}$ & $\begin{array}{l}\text { Tota } \\
1\end{array}$ & $\begin{array}{l}\text { Tot } \\
\text { al }\end{array}$ \\
\hline Spain & 48.3 & 48.0 & 18.1 & 21.7 & 28.5 & 28.1 & 9.0 & 35.0 & 10.1 & 44.1 & 14.7 & 16.8 & 8.7 & 24.3 & 7.7 \\
\hline France & 24.7 & 23.4 & 18.8 & 19.5 & 14.0 & 13.7 & 10.1 & 28.8 & 24.3 & 35.3 & 32.3 & 9.1 & 7.2 & 11.9 & 8.8 \\
\hline Poland & 20.8 & 20.9 & 21.7 & 23.8 & 10.1 & 9.8 & 10.6 & 29.2 & 34.6 & 35.9 & 45.5 & 6.8 & 7.1 & 8.5 & 8.7 \\
\hline Sweden & 20.4 & 19.6 & 19.3 & 19.8 & 8.7 & 8.4 & 7.0 & 6.3 & 4.0 & 15.5 & 11.0 & 11.2 & 10.1 & 7.5 & 6.1 \\
\hline UK & 14.6 & 12.9 & 14.3 & 12.5 & 6.0 & 5.6 & 4.9 & 21.9 & 15.7 & 28.7 & 23.7 & 8.6 & 8.8 & 5.1 & 4.2 \\
\hline Estonia & 13.1 & 12.2 & 10.1 & 7.2 & 6.0 & 7.1 & 4.4 & 15.5 & 30.5 & 34.7 & 46.8 & 5.5 & 3.8 & 5.1 & 3.7 \\
\hline $\begin{array}{l}\text { Netherlan } \\
\text { ds }\end{array}$ & 11.3 & 11.2 & 5.9 & 6.2 & 6.5 & 6.3 & 2.4 & 18.7 & 12.6 & 31.5 & 26.2 & 7.7 & 4.3 & 5.7 & 2.2 \\
\hline Germany & 7.2 & 6.5 & 11.9 & 11.1 & 5.8 & 4.9 & 9.9 & 22.5 & 32.2 & 32.2 & 42.7 & 3.5 & 6.1 & 4.8 & 8.1 \\
\hline $\mathbf{E U}$ & 20.4 & 19.5 & 15.5 & 15.9 & 12.4 & 12.3 & 8.7 & 32.4 & 26.4 & 43.0 & 36.8 & 8.4 & 6.8 & 10.2 & 7.1 \\
\hline
\end{tabular}

Source: Eurostat 
Table 0.2 Employment Rate within Three Years after Highest Educational Attainment (ISCED), NEET rate,

Fixed-Term Employment Rate of 15-29 year olds - 2007 and 2015 (\%)

\begin{tabular}{|c|c|c|c|c|c|c|c|c|c|c|c|}
\hline \multirow{3}{*}{ Country } & \multicolumn{5}{|c|}{ Employment Rate within 3 Years } & \multicolumn{4}{|c|}{ NEET Rate } & \multirow{2}{*}{\multicolumn{2}{|c|}{$\begin{array}{c}\text { Fixed-Term } \\
(15-29)\end{array}$}} \\
\hline & \multicolumn{2}{|c|}{ Total } & & \multirow{2}{*}{\begin{tabular}{|c|c}
$\begin{array}{c}3-4 \\
\text { (ISCED) }\end{array}$ \\
2015
\end{tabular}} & \multirow{2}{*}{$\begin{array}{c}5-8 \\
\text { (ISCED) }\end{array}$} & \multicolumn{2}{|c|}{$15-24$} & \multicolumn{2}{|c|}{$25-29$} & & \\
\hline & 2015 & 2007 & & & & 2015 & 2007 & 2015 & 2007 & 2015 & 2007 \\
\hline Germany & 86.9 & 77.8 & 44.1 & 87.3 & 92.4 & 6.2 & 12.0 & 12.3 & 16.9 & 38.1 & 41.5 \\
\hline Netherlands & 84.8 & 84.3 & 67.6 & 83.9 & 89.1 & 4.7 & 3.5 & 10.6 & 7.6 & 44.2 & 37.0 \\
\hline Sweden & 83.2 & 82.4 & 61.6 & 79.2 & 90.8 & 6.7 & 7.5 & 8.6 & 8.8 & 41.0 & 43.6 \\
\hline$\overline{\text { UK }}$ & 76.9 & 79.3 & 41.2 & 72.8 & 85.5 & 11.1 & 11.9 & 15.4 & 14.9 & 11.3 & 10.3 \\
\hline Estonia & 74.8 & 76.0 & 32.7 & 71.8 & 84.8 & 10.8 & 8.9 & 14.8 & 17.2 & 8.0 & 4.2 \\
\hline Poland & 73.3 & 70.5 & 23.7 & 64.7 & 83.7 & 11.0 & 10.6 & 20.5 & 21.6 & 54.3 & 49.5 \\
\hline France & 62.8 & 70.6 & 21.4 & 57.0 & 77.9 & 11.9 & 10.7 & 20.0 & 17.2 & 41.0 & 35.5 \\
\hline Spain & 54.2 & 74.4 & 29.2 & 47.5 & 66.7 & 15.6 & 12.0 & 26.0 & 13.8 & 54.3 & 51.5 \\
\hline $\mathbf{E U}$ & 69.8 & 73.5 & 33.1 & 66.5 & 79.7 & 12.0 & 11.0 & 19.7 & 17.2 & 32.5 & 30.9 \\
\hline
\end{tabular}

Source: Eurostat

Table 0.3 Educational Attainment by Age and ISCED Level (2015)

\begin{tabular}{|l|r|r|r|r|r|r|}
\hline \multirow{2}{*}{ Country } & \multicolumn{3}{|c|}{$\mathbf{2 0 - 2 4}$} & \multicolumn{3}{|c|}{$\mathbf{2 5 - 3 4}$} \\
\cline { 2 - 7 } & $\mathbf{0 - 2}$ & $\mathbf{3 - 4}$ & $\mathbf{5 - 8}$ & $\mathbf{0 - 2}$ & $\mathbf{3 - 4}$ & $\mathbf{5 - 8}$ \\
\hline Spain & 31.5 & 46.9 & 21.5 & 34.4 & 24.6 & 41.0 \\
\hline Germany & 22.9 & 70.7 & 6.4 & 12.7 & 57.7 & 29.6 \\
\hline Netherlands & 20 & 61.7 & 18.3 & 14.4 & 40.5 & 45.1 \\
\hline Estonia & 16.7 & 69.5 & 13.8 & 10.8 & 48.6 & 40.6 \\
\hline UK & 14.3 & 56.2 & 29.5 & 14.7 & 38.4 & 47.0 \\
\hline France & 12.8 & 58.3 & 28.8 & 13.5 & 41.9 & 44.7 \\
\hline Sweden & 12.7 & 69.8 & 17.5 & 12.1 & 41.4 & 46.5 \\
\hline Poland & 9.2 & 76.3 & 14.5 & 6.1 & 50.7 & 43.2 \\
\hline EU & $\mathbf{1 7 . 3}$ & $\mathbf{6 5 . 5}$ & $\mathbf{1 7 . 2}$ & $\mathbf{1 6 . 6}$ & $\mathbf{4 5 . 6}$ & $\mathbf{3 7 . 9}$ \\
\hline
\end{tabular}

Source: Eurostat 